\title{
The Leadership Styles of the Local Universities and Colleges' Administrators
}

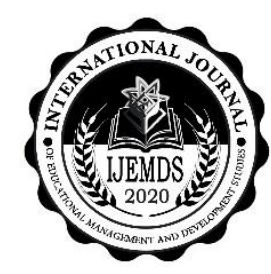

\author{
Patricia Sonia Elardo-Zabala
}

\begin{abstract}
This study determined the leadership styles of the administrators of the local universities and colleges (LUCs) in the provinces of Cavite, Laguna, Batangas, Rizal and Quezon commonly known as CALABARZON Region in the Philippines. The descriptive-evaluative method of research was used. Data were gathered using a self-constructed Likert type questionnaire from the one-hundred eleven (111) randomly selected administrators. The statistical tools applied were weighted mean, Pearson $r$, and single factor Analysis of Variance (ANOVA). Findings revealed that charismatic and command and control showed significant difference in the responses on leadership style practices when grouped as to provinces as contrasted with innovative, laissez-faire, pace setter, servant, and situational which showed no significant statistical difference. Though the leadership style practices of the school administrators were clearly manifested as to style, efforts may be directed to further strengthen trust since people are the lifeblood of the organization, thus, they must be valued. Also, as leaders of educational institutions, they should employ approaches that are appropriate for different sets of purposes or circumstances to further improve the relationship with the team.
\end{abstract}

Keywords:

leadership style, local universities and colleges, charismatic leadership, innovative leadership, servant leadership

Suggested Citation: Zabala, P.E. (2021). The Leadership Styles of Locally Funded Universities and Colleges' Administrators. International Journal of Educational Management and Development Studies, Volume 2, Issue 2, pp. 20 - 37.

\footnotetext{
About the author:

Doctor of Philosophy Graduate at Southern Luzon State University
} 


\section{Introduction}

According to Eagly (2013), men and women have different leadership styles but the variances do not mean that one has dominance over the other. The difference may be due in part to men seeing leadership as leading (Ciolac, 2013), and women seeing leadership as facilitating (Naz, 2010). Although male and female administrators perform many of the same tasks in carrying out their work, different aspects of the job are emphasized. Women educational administrators focus on instructional leadership in supervisory practices and are concerned with students' individual differences, knowledge of curriculum, teaching methods, and the objectives of teaching. In the area of instructional leadership, women spend more years as principals and teachers, and have more degrees than men; they emphasized the importance of curriculum and instruction in their work (Eagly, 2013; Kuchynková, 2015; Radu, Deaconu \& Frăsineanu, 2017).

Relating values, customs, and lifestyle to leadership styles, one will never fail to recognize differences in the form of leading. Each leader has his or her own unique style. Effective leaders vary their methods based on the context, the individuals concerned, and the desired outcome. According to Blanken (2013), leading well means not just one leadership style. It is mixed and matched to engage team to meet goals. If one is aware of the different ways of leading, he/she can adapt any leadership style to manage circumstances and/or decide which style to use. Some of the common leadership styles are charismatic, innovative, command and control, laissez-faire, pace-setter, servant, and situational leaders.

This evaluated the leadership styles of the LUCs' administrators in the CALABARZON Region. It specifically assessed the leadership style according to Blanken (2013) as charismatic, innovative, command and control, laissez-faire, pace setter, servant and situational. It also ascertained the significant difference in the leadership styles of LUCs administrators in the CALABARZON Region.

The hypothesis of the study follows:

HO1: There is no significant difference in the leadership styles of the LUCs administrators when grouped according to province. 


\section{Literature review}

\subsection{Leadership Style}

No style is good or bad. Leadership is an acquired attribute that begins early in school. As time goes on, education, jobs, and life experiences shape a leader's philosophy and psychology. How best to get the job done, how to set goals and objectives and manage their results, become a leader's winning formula for success. However, over time, a leader may find that her winning formula is not producing the results it used to. There is a time and place for all leadership style. New challenges require new leadership skills, behaviors, and ways of communicating (Blanken, 2013; Sirisookslip, Ariratana \& Ngang, 2015). It is time to unlearn familiar leadership approach, recognize limitations, and adapt leadership style to become the leader one imagines to be. Leadership lives on how one thinks, not what one thinks. In the result of Blanken's study (2013), common leadership styles identified were: charismatic leaders; innovative leaders; command and control leaders; laissez-faire leaders; pace setter leaders; servant leaders; and situational leaders.

Charismatic leaders are individuals who influence others through power of personality, act energetically, and motivate others to move forward (Sacavem, et al., 2017). Charismatic Leaders are leaders who possess certain qualities that inspire people and encourage devotion to a certain cause (Blanken, 2013). Charismatic leadership is a throwback to the old conception of leaders as being those who "by the force of their personal abilities are capable of having profound and extraordinary effects on followers". Although the charismatic concept or charisma, goes as far back as the ancient Greeks, its modern development is often attributed to the work of Robert House.

On the basis of the analysis of political and religious leaders, House suggest that charismatic leaders are characterized by self-confidence and confidence in their associates, high expectations for associates, ideological vision, and the use of personal example. Followers of charismatic leaders identify with the leader and the mission of the leader, exhibit extreme loyalty to and confidence in the leaders, emulate the leader's values and behavior, and derive self-esteem from the relationship with the leader (Nikoloski, 2015). House has extended the profile of charismatic leaders to include superior debating and persuasive skills as well as technical expertise and the fostering of attitudinal, behavioral, and 
emotional changes in their followers (Luthans 2011). Some known charismatic leaders are Winston Churchill, Mahatma Gandhi, Mother Teresa.

Innovative leaders are individuals who can grasp the entire situation and go beyond the usual course of action (Rahman, 2012). They can see what is not working and brings new thinking and action into play. According to Blanken (2013), one of her icon as innovative leader is Richard Branson, who at the age of sixteen launched his Virgin Group of companies now comprising more than 400 companies in the fields ranging from music to space tourism. Branson described his philosophy to Inc. Magazine: "Dream big by setting yourself seemingly impossible challenges. You then have to catch up with them." Blanken also added that innovative leaders know when to break intractable issues and create a work climate for others to apply innovative thinking to solve problems, develop new products and services. The impact on others are, of course, risk taking is increased for all, failures do not impede progress, team gains job satisfaction and enjoyment, and atmosphere of respect for others' ideas is present (Blanken, 2013).

Command and Control leaders are persons who learned to adapt leadership style to improve relationship with his team but never lost sight of his goal. They demand immediate compliance, the sole decision maker, and engage in top-down interactions (Podhorec, Hriník \& Lakoš, 2017). They follow the rules and expect others to do the same. This leadership style uses standards, procedures, and output statistics to regulate the organization. A command and control approach to leadership is authoritative in nature and uses a top-down approach which fits well in bureaucratic organizations in privilege and power are vested in senior management (Blanken, 2013).

Command and control are by far the most common leadership style. Most of today's leaders were mentored themselves by command and control managers, and the culture of most organizations is still based on command and control norms. It is difficult to escape this leadership style's historic influence and dominance.

Laissez-Faire leaders are individuals who know what is happening but not directly involved in it. Their vision lives on in the work of others, inspired by their leadership (Blanken, 2013; Ekmekci \& Tosunoglu, 2016; Jarc, 2015).

Laissez-faire leadership is a non-authoritarian style of leading people, where leaders try to give the least possible guidance to their subordinates and achieve control through less 
obvious means (Robert \& Vandenberghe, 2020). These leaders believe that people would excel if left alone to respond to their obligations and responsibilities in their own ways. Laissez faire is also known as delegative leadership, it sees leaders being hand-off and allow group members to do some decision-making. Kurt lewin, a contributor to social psychology, is often credited as the developer of the laissez faire leadership concept. He identified laissez faire leadership as the opposite of autocratic leadership whereby the Chief Executive Officer (CEO) makes most of the decisions and relies on his subordinates to carry out instructions. Lewin, et al, deduced that neither laissez faire nor autocratic leaders styles were ideal and rather concluded that the optimal style is democratic leadership (J.Cris, 2015).

Pace Setter Leaders are individuals who set high performance standards for self and the group. They know that when staff are self-motivated and highly skilled, they can embrace new projects and move with speed (Blanken, 2013).

The phrase that best describes the operating mode of the pacesetting leader is "Do as I do, and do it now". That is because this style involves a drive to achieve initiatives, and a drive to achieve results. Pacesetters set high standards for themselves and those they are leading. One of the key attributes of a pacesetting leader is that they lead by example. They don't ask their followers to do anything they would not do themselves. They are also quick to identify individuals that are not keeping pace with their expectations. Pacesetters do not give employees a lot of positive feedback; they simply do not have the time. He is obsessive about doing things better and faster (never satisfied with the status quo), and he asks the same of everyone around him. He is intolerant of poor performers and demanding more from them and if improvements are not forthcoming, terminates them. Also, pacesetters tend to have trouble trusting their followers. Their self-esteem rests on being smarter, faster and more thorough than everyone else. Normally, the followers of a pacesetter leaders are technically skilled, highly motivated, and competent; already fit with the pacesetter's expectations (Henson, 2013).

Servant leaders are persons who put service to others before self-interest. They stay out of limelight and let the team accept credit for results (Blanken, 2013).

The idea of servant leadership goes back at least two thousand years ago, while the modern servant leadership movement was launched by Robert K. Greenleaf in 1970 with his classic essay, The Servant as Leader. It was in this article that he coined the words "servant- 
leader" and "servant-leadership". Greenleaf said that "the servant-leader is servant first" and that he has a "servant's heart". It is not about being servile; it is about wanting to help others. It is about identifying and meeting the needs of colleagues, customers, and communities. Greenleaf said that a single characteristic of the servant-leader that stands out in Greenleaf's essay, it is the desire to serve. Greenleaf describes servant-leaders as people who initiate action, are goal-oriented, are dreamers of great dreams, are good communicators, are able to withdraw and re-orient themselves, and are dependable, trusted, creative, intuitive, empowering and developing people, humble, authentic, providing direction and stewardship (Keith, 2017).

Situational Leaders are persons who link behavior with group's readiness. They include being directing and supportive, while empowering and coaching (Blanken, 2013). Situational Leadership Theory is the short form for "Hersey-Blanchard Situational Leadership Theory" and draws major views from contingency thinking. As the name implies, leadership depends upon each individual situation, and no single leadership style can be considered the best. For Hershey and Blanchard, tasks are different and each type of task requires a different leadership style. A good leader will be able to adapt her or his leadership to the goals or objectives to be accomplished. Goal setting, capacity to assume responsibility, education, and experience are main factors that make a leader successful. Not only is the leadership style important for a successful leader-led situation but the ability or maturity of those being led is a critical factor as well. Leadership techniques fall out of the leader pairing her or his leadership style to the maturity level of the group.

\section{Methodology}

The descriptive-evaluative method to describe people who take part in the study (Fraenkel, 2007) was utilized. There were fifteen (15) LUCs in the region listed in the Commission on Higher Education (2017) which include City College of Tagaytay, Trece Martires City College, Balian Community College, City College of Calamba, Dalubhasaan ng Lungsod ng San Pablo, Laguna University, Pamantasan ng Cabuyao, Colegio ng Lungsod ng Batangas, Kolehiyo ng Lungsod ng Lipa, Tanauan City College, Antipolo Institute of Technology, Colegio de Montalban, San Mateo Municipal College, Dalubhasaan ng Lungsod 
ng Lucena and Pambayang Kolehiyo ng Mauban. These colleges and universities were represented by a total of 111 administrators as the main respondents.

The study used a self-made questionnaire in a 5-point Likert-scale type. The pilot testing was conducted with ten (10) administrators as participants. The Cronbach's Alpha was also utilized to determine the extent or range of error correction. Subsequently, the instrument was corrected and validated before distribution to the target respondents.

The researcher set schedule for the administration of the instruments and personally conducted the data gathering. Only those who were present were considered participants.

The Weighted Mean and Single Factor ANOVA was used for data analysis. The following were the verbal interpretation of the responses:

5 Very Good (VG) The leadership practices are observed from 81-100\%.

4 Good $(\mathrm{G}) \quad$ The leadership practices are observed from $61-80 \%$.

3 Satisfactory (S) The leadership practices are observed from 41-60\%.

2 Fair (F) The leadership practices are observed from $21-40 \%$.

1 Poor (P) The leadership practices are observed from 1-20\%.

\section{Findings and Discussion}

Table 1

Leadership Style Practices as to Charismatic Leaders

\begin{tabular}{lcc}
\hline \multicolumn{1}{c}{ Indicators } & WM & QD \\
\hline $\begin{array}{l}\text { The administrators ... } \\
\text { 1. Provide inspiring and strategic management goals. }\end{array}$ & 4.32 & VG \\
$\begin{array}{l}\text { 2. Able to motivate by articulating effectively the importance of what } \\
\text { organizational members are doing. }\end{array}$ & 4.31 & VG \\
$\begin{array}{l}\text { 3. Consistently generate new ideas for the future of the organization. } \\
\begin{array}{l}\text { 4. Have vision and often brings up ideas about possibilities for the } \\
\text { future. }\end{array}\end{array}$ & 4.32 & VG \\
$\begin{array}{l}\text { 5. Seize new opportunities in order to achieve goals. } \\
\begin{array}{l}\text { 6. Readily recognize new environmental opportunities (favorable physical } \\
\text { and social conditions) that may facilitate achievement of organizational } \\
\text { objectives. }\end{array}\end{array}$ & 4.25 & VG \\
\hline \multicolumn{1}{c}{ Average Weighted Mean } & VG \\
\hline
\end{tabular}


Table 1 shows the frequency and weighted mean distribution of the responses on leadership style practices as to charismatic leaders.

The general weighted mean is 4.31 with a verbal interpretation of "Very Good." This implies that the administrators highly practice this type of leadership. This is evident on the highest indicators, which are statement nos. 1, 2, 3, and 4 with weighted means of 4.32, 4.31, 4.32, and 4.37, respectively. It amplifies that the administrators provide inspiring and strategic management goals, able to motivate by articulating effectively the importance of what organizational members are doing, consistently generate new ideas for the future of the organization, and have vision and often brings up ideas about possibilities for the future.

The lowest indicators are item nos. 5 and 6 with weighted means of 4.27 and 4.25 , respectively. It reveals that the administrators seize new opportunities in order to achieve goals and readily recognize new environmental opportunities (favorable physical and social conditions) that may facilitate achievement of organizational objectives.

As stated by Blanken (2013), charismatic leaders are individuals who influence others through power of personality, act energetically, and motivate others to move forward. Charismatic leaders possess certain qualities that inspire people and encourage devotion to a certain cause. It is very evident that the respondents rated very good all the administrators of the LUCs in CALABARZON.

\section{Table 2}

\section{Leadership Style Practices as to Innovative Leaders}

\section{Indicators}

The administrators ...

1. Are comfortable with uncertainty and have open mind.

2. Are receptive to ideas from very different disciplines.

3. Have the tools and skills to pinpoint and manage the risks inherent in innovation.

4. Are capable of adapting their behaviors to the requirements of certain situations that might appear.

5. Have to be able to mobilize and motivate the team and make it aim towards "new."

6. Have the abilities and qualities in order to push for innovation in the activity field of the organization.

\section{WM}

QD

4.27

VG

$4.31 \quad$ VG

4.17

G

4.30

VG

4.25

4.27

4.26

$\begin{array}{lcc}\text { Average Weighted Mean } & 4.26 & \text { VG }\end{array}$


Table 2 shows the frequency and weighted mean distribution of the responses on leadership style practices as to innovative leaders. The general weighted mean is 4.26 with a verbal interpretation of "Very Good." This implies that this leadership style is practiced by the school administrators with 'very good' rating.

The highest rates are on statement nos. 1, 2, 4 and 6 with weighted means of 4.27, 4.31, 4.30, and 4.27, respectively. It elicited that the administrators are comfortable with uncertainty and have open mind, are receptive to ideas from very different disciplines, are capable of adapting their behaviors to the requirements of certain situations that might appear, and have the abilities and qualities in order to push for innovation in the activity field of the organization. The lowest rates are on item nos. 3 and 5 with weighted means of 4.17 and 4.25 , respectively. This exemplifies that the administrators have the tools and skills to pinpoint and manage the risks inherent in innovation, and have to be able to mobilize and motivate the team and make it aim towards "new."

Innovative leaders are individuals who can grasp the entire situation and go beyond the usual course of action. They can see what is not working and bring new thinking and action into play. Innovative leaders know when to break intractable issues and create a work climate for others to apply innovative thinking to solve problems, develop new products and services (Blanken, 2013). Indicator number three got a score of only good, which means that the tools and skills to pinpoint and manage the risks inherent in innovation were not that satisfactory for the respondents.

Table 3 shows the frequency and weighted mean distribution of the responses on leadership style practices as to command and control leadership. The general weighted mean is 4.17 with a verbal interpretation of "Good." This implies that this leadership style is practiced by the school administrators with 'good' rating.

The top scorers are statement nos. 1, 4, 6 and 7 with weighted means of 4.19, 4.17, 4.25 , and 4.22, respectively. It revealed that the administrators decide based on the collective behavior in an organization, establish the conditions under which sense making and execution take place, employ approaches that are appropriate for different sets of purposes or circumstances, and utilize approaches that may be taken by different sets of entities in an enterprise, may change over time. 
Table 3

Leadership Style Practices as to Command and Control Leaders

\begin{tabular}{|c|c|c|}
\hline Indicators & $\mathbf{W M}$ & QD \\
\hline \multicolumn{3}{|l|}{ The administrators ... } \\
\hline 1. Decide based on the collective behavior in an organization. & 4.19 & $\mathrm{G}$ \\
\hline $\begin{array}{l}\text { 2. Apply to endeavors undertaken by collections of individuals and } \\
\text { organizations of vastly different characteristics and sizes for many different } \\
\text { purposes. }\end{array}$ & 4.12 & G \\
\hline $\begin{array}{l}\text { 3. Determine the bounds within which behavior(s) are to take place, not the } \\
\text { specific behaviors themselves. }\end{array}$ & 4.16 & $\mathrm{G}$ \\
\hline $\begin{array}{l}\text { 4. Establish the conditions under which sense making and execution take } \\
\text { place. }\end{array}$ & 4.17 & G \\
\hline $\begin{array}{l}\text { 5. Apply to all subsets of an enterprise, to the functions performed, to the } \\
\text { levels of organizations, to the focus of the activity, whether strategic or } \\
\text { tactical. }\end{array}$ & 4.11 & $\mathrm{G}$ \\
\hline $\begin{array}{l}\text { 6. Employ approaches that are appropriate for different sets of purposes or } \\
\text { circumstances. }\end{array}$ & 4.25 & VG \\
\hline $\begin{array}{l}\text { 7. Utilize approaches that may be taken by different sets of entities in an } \\
\text { enterprise, may change over time. }\end{array}$ & 4.22 & VG \\
\hline Average Weighted Mean & 4.17 & $\mathbf{G}$ \\
\hline
\end{tabular}

The bottom scorers are statement nos. 2, 3, and 5 with weighted means of 4.12, 4.16, and 4.11, respectively. This illustrates that the administrators apply to endeavors undertaken by collections of individuals and organizations of vastly different characteristics and sizes for many different purposes, determine the bounds within which behavior(s) are to take place, not the specific behaviors themselves, and apply to all subsets of an enterprise, to the functions performed, to the levels of organizations, to the focus of the activity, whether strategic or tactical.

Command and control leader is a person who learned to adapt leadership style to improve his relationship with his team but never lost sight of his goal: win! He/she is a person who demands immediate compliance, the sole decision maker, and engages in topdown interactions. He/she follows the rules and expects others to do the same. 
Table 4

Leadership Style Practices as to Laissez-Faire Leaders

\begin{tabular}{lcc}
\hline \multicolumn{1}{c}{ Indicators } & WM & QD \\
\hline $\begin{array}{l}\text { The administrators ... } \\
\text { 1. Should allow members work out problems on their own. }\end{array}$ & 3.91 & $\mathrm{G}$ \\
$\begin{array}{l}\text { 2. Are required staying out of the way of members as they do their work. } \\
\text { 3. Should allow members to appraise their own work. }\end{array}$ & 3.84 & $\mathrm{G}$ \\
$\begin{array}{l}\text { 4. Should grant members complete freedom to solve problems on their } \\
\text { own. }\end{array}$ & 3.99 & $\mathrm{G}$ \\
$\begin{array}{l}\text { 5. Prefer little input from the leader. } \\
\text { 6. Leave members alone. }\end{array}$ & 3.89 \\
7. Encourage teamwork among members. & 3.34 & $\mathrm{G}$ \\
\hline Average Weighted Mean & 4.34 & $\mathrm{~S}$ \\
\hline
\end{tabular}

Table 4 shows the frequency and weighted mean distribution of the responses on leadership style practices as to laissez-faire leaders. The general weighted mean is 3.85 with a verbal interpretation of "Good." This implies that this leadership style of the school administrators gained a good rating.

The highest items are nos. 1, 3, 4, and 7 with weighted means of 3.91, 3.99, 3.89, and 4.34, respectively. It shows that the administrators should allow members work out problems on their own, should allow members to appraise their own work, should grant members complete freedom to solve problems on their own, and encourage teamwork among members.

The lowest items are nos. 2, 5, and 6 with weighted means of 3.84, 3.65, and 3.34, respectively. This explains that the administrators are required staying out of the way of members as they do their work, prefer little input from the leader, and leave members alone.

Laissez-Faire leaders are individuals who know what is happening but not directly involved in it. They vision lives on in the work of others, inspired by their leadership (Blanken, 2013). Also, by definition, laissez faire leadership is a non-authoritarian style of leading people, where leaders try to give the least possible guidance to their subordinates and achieve control through less obvious means. These type of leaders believe that people would excel if left alone to respond to their obligations and responsibilities in their own ways. Laissez faire is also known as delegated leadership; it sees leaders being hand-off and allows group members to do some decision-making. This is what the researcher found out, that the 
respondents rated low when it comes to the indicator that members are left alone. It practically means that majority of the LUCs administrators are hands-on and aware of what is going on in the institution.

\section{Table 5}

Leadership Style Practices as to Pace Setter Leaders

\begin{tabular}{lcc}
\hline \multicolumn{1}{c}{ Indicators } & WM & QD \\
\hline The administrators ... & & \\
1. Feel overwhelmed by the pacesetter's demand for excellence. & 4.17 & $\mathrm{G}$ \\
$\begin{array}{l}\text { 2. Set collaborative standards. } \\
\text { 3. Achieve the target most of the time. }\end{array}$ & 4.27 & $\mathrm{VG}$ \\
4. Are obsessed with doing things better and faster than everyone. & 4.20 & $\mathrm{VG}$ \\
5. Expect subordinate to excel in the same way as he does. & 3.95 & $\mathrm{G}$ \\
6. Expect subordinate to excel in the same way as he does. & 3.97 & $\mathrm{G}$ \\
7. Make feedback practically no-existent. & 3.73 & $\mathrm{G}$ \\
\multicolumn{1}{c}{ Average Weighted Mean } & 3.57 & $\mathrm{G}$ \\
\hline
\end{tabular}

Table 5 shows the frequency and weighted mean distribution of the responses on leadership style practices as to pace setter leaders. The general weighted mean is 3.98 with a verbal interpretation of "Good." This leadership style is practiced by the school administrators with a good rating.

The top indicators are statement nos. 1, 2, and 3 with weighted means of 4.17, 4.27, and 4.20, respectively. It connotes that the administrators feel overwhelmed by the pacesetter's demand for excellence, set collaborative standards, and achieve the target most of the time. The bottom indicators are statement nos. 4, 5, 6, and 7 with weighted means of $3.95,3.97,3.73$, and 3.57, respectively. It shows that the administrators are obsessed with doing things better and faster than everyone, expect subordinate to excel in the same way as he does, expect subordinate to excel in the same way as he does, and make feedback practically no-existent.

Pacesetter leaders are individuals who set high performance standards for self and the group. They know that when staff are self-motivated and highly skilled, they can embrace new projects and move with speed. The operating mode of the pace setter leader is "Do as I do, and do it now". Pacesetters set high standards for themselves and those they are leading. 
They do not ask their followers to do anything they would not do themselves. They are obsessed on doing things better and faster (never satisfied with the status quo) (Henson, 2013). This means that the LUCs administrators are simply good when it comes to being a pacesetter leader. It is obvious that they still have to consult the higher authorities before they actually act on one program.

\section{Table 6}

Leadership Style Practices as to Servant Leaders

\begin{tabular}{|c|c|c|}
\hline Indicators & WM & QD \\
\hline $\begin{array}{l}\text { The administrators ... } \\
\text { 1. Give others the responsibility to make important decisions about their } \\
\text { own jobs. }\end{array}$ & 4.13 & G \\
\hline 2. Encourage others to handle important work decisions on their own. & 4.15 & G \\
\hline 3. Have a thorough understanding of the organization and its goals. & 4.49 & VG \\
\hline $\begin{array}{l}\text { 4. Give others the freedom to handle difficult situations in the way they } \\
\text { feel is best. }\end{array}$ & 4.18 & G \\
\hline $\begin{array}{l}\text { 5. Provide others with work experiences that enable them to develop } \\
\text { new skills. }\end{array}$ & 4.30 & VG \\
\hline 6. Sacrifice his/her own interests to meet others' needs. & 4.09 & G \\
\hline 7. Can recognize when others are feeling down without asking them. & 4.14 & G \\
\hline Average Weighted Mean & 4.21 & VG \\
\hline
\end{tabular}

Table 6 shows the frequency and weighted mean distribution of the responses on leadership style practices as to servant leaders. The general weighted mean is 4.21 with a verbal interpretation of "Very Good." This implies that these leadership style practices of the school administrators gained a very good rating.

The highest rates are on item nos. 3 and 5 with weighted means of 4.49 and 4.30 , respectively. This illuminates that the administrators have a thorough understanding of the organization and its goals and provide others with work experiences that enable them to develop new skills.

The lowest rates are on item nos. 1, 2, 4, 6 and 7 with weighted means of 4.13, 4.15, 4.18, 4.09, and 4.14, respectively. This illustrates that the administrators give others the responsibility to make important decisions about their own jobs, encourage others to handle important work decisions on their own, give others the freedom to handle difficult situations 
in the way they feel is best, sacrifice his/her own interests to meet others' needs, and can recognize when others are feeling down without asking them.

Servant leaders are persons who put service to others before self-interest. They stay out of limelight and let the team accept credit for results (Blanken, 2013). While according to Robert K. Greenleaf, the person who coined servant leadership, stated that "the servantleader is servant first" and that he has a "servant's heart". It is not about being servile; it is about wanting to help others (Keith, 2017).

This proves true that the leadership of LUCs in the CALABARZON region were rated 'very good' by the respondents since most of them are civil servant administrators. They are trained to practice servant leadership although there are some indicators that were only rated good by the respondents.

\section{Table 7}

\section{Leadership Style Practices as to Situational Leaders}

\begin{tabular}{lcc}
\hline \multicolumn{1}{c}{ Indicators } & WM & QD \\
\hline The administrators ... & & \\
$\begin{array}{l}\text { 1. Are willing to take responsibility for directing their own behavior. } \\
\text { 2. Reduce task behavior and increase relationship behavior. }\end{array}$ & 4.33 & VG \\
$\begin{array}{l}\text { 3. Spend more time directing the person in what to do and how, when, } \\
\text { and where to do it, than providing socioemotional support and }\end{array}$ & 3.81 & G \\
reinforcement. & & \\
$\begin{array}{l}\text { 4. Develop the follower slowly, using a little less task behavior and a } \\
\text { little more relationship behavior as the follower increases in readiness. }\end{array}$ & 3.92 & G \\
$\begin{array}{l}\text { 5. Reduce a little of the structure or direction (task behavior) by giving } \\
\text { the follower an opportunity to assume some increased responsibility. }\end{array}$ & 4.09 & G \\
6. Reinforce the behavior with increases in relationship behavior. & 4.14 & G \\
\hline Average Weighted Mean & $\mathbf{4 . 0 7}$ & G \\
\hline
\end{tabular}

Table 7 below shows the frequency and weighted mean distribution of the responses on leadership style practices as to situational leaders. The general weighted mean is 4.07 with a verbal interpretation of "Good." This implied that the leadership style practices of the school administrators gained a good rating.

The top scorers are item nos. 1, 2, 5, and 6 with weighted means of 4.33, 4.10, 4.09 and 4.14, respectively. It indicates that the administrators are willing to take responsibility for directing their own behavior, reduce task behavior and increase relationship behavior, reduce a 
little of the structure or direction (task behavior) by giving the follower an opportunity to assume some increased responsibility, and reinforce the behavior with increases in relationship behavior.

The bottom scorers are item nos. 3 and 4 with weighted means of 3.81 and 3.92, respectively. It amplifies that the administrators spend more time directing the person in what to do and how, when, and where to do it, than providing socio-emotional support and reinforcement, and develop the follower slowly, using a little less task behavior and a little more relationship behavior as the follower increases in readiness.

Situational Leaders are persons who link behavior with group's readiness. They include being directing and supportive, while empowering and coaching (Blanken, 2013). While HerseyBlanchard Situational Theory stated that leadership depends upon each individual situation, and no single leadership style can be considered the best. However, the respondents rated most of the indicators simply good, which probably according to them, some of the administrators were not very good when it comes to situational leadership.

Table 8

Differences of the Responses on Leadership Style Practices When Grouped As to Provinces

\begin{tabular}{|c|c|c|c|c|c|c|}
\hline & $\begin{array}{c}\text { Sum of } \\
\text { Squares }\end{array}$ & df & $\begin{array}{c}\text { Mean } \\
\text { Square }\end{array}$ & $\mathbf{F}$ & Sig & Analysis \\
\hline Charismatic between groups & 193.44 & 4 & 48.36 & 3.58 & .01 & $\mathrm{~S}$ \\
\hline Within groups & 1392.19 & 103 & 13.52 & & & \\
\hline Total & 1585.63 & 107 & & & & \\
\hline Innovative between groups & 135.20 & 4 & 33.80 & 2.12 & .08 & NS \\
\hline Within groups & 1677.86 & 105 & 15.98 & & & \\
\hline Total & 1813.06 & 109 & & & & \\
\hline Command \& control between groups & 362.33 & 4 & 90.58 & 4.65 & .01 & $\mathrm{~S}$ \\
\hline Within groups & 2005.77 & 103 & 19.47 & & & \\
\hline Total & 2368.10 & 107 & & & & \\
\hline Laissez faire between groups & 287.15 & 4 & 71.79 & 3.12 & .02 & NS \\
\hline Within groups & 2302.70 & 100 & 23.03 & & & \\
\hline Total & 2589.85 & 104 & & & & \\
\hline Pace setter between groups & 174.03 & 4 & 43.51 & 1.95 & .11 & NS \\
\hline Within groups & 2119.76 & 95 & 22.31 & & & \\
\hline Total & 2293.79 & 99 & & & & \\
\hline Servant between groups & 260.48 & 4 & 65.12 & 3.15 & .02 & NS \\
\hline Within groups & 2171.02 & 105 & 20.68 & & & \\
\hline Total & 2431.50 & 109 & & & & \\
\hline Situational between groups & 205.12 & 4 & 51.28 & 2.88 & .03 & NS \\
\hline Within groups & 1850.70 & 104 & 17.80 & & & \\
\hline Total & 2055.82 & 108 & & & & \\
\hline
\end{tabular}


Table 8 shows the differences of the responses on leadership style practices when grouped as to provinces. In terms of charismatic and command and control, the F computed values are all far greater than the F critical value of 3.41. Thus, the null hypothesis is rejected. There exists a significant difference on the responses on leadership style practices when grouped as to provinces.

As contrasted, along with innovative, laissez-faire, pace setter, servant, and situational, the F computed values are all far less than the F critical value of 3.41. Thus, the null hypothesis is accepted. There is no significant difference in the responses on leadership style practices when grouped as to provinces.

\section{Conclusion}

The leadership style practices of the school administrators showed very good manifestations of charismatic, innovative and servant leadership styles while good evidence of command and control, laissez-faire, pace-setter and situational leadership styles. The differences of the responses on leadership style practices when grouped as to provinces, in terms of charismatic and command and control, the F computed values were all far greater than the F critical value of 3.41. Thus, the null hypothesis is rejected. As contrasted, along with innovative, laissez-faire, pace setter, servant, and situational, the F computed values were all far less than the F critical value of 3.41. Thus, the null hypothesis is accepted. Correspondingly, there is no significant difference in the responses on leadership styles of LUCs administrators in the CALABARZON region when grouped as to provinces.

Though the leadership style practices of the school administrators are perceived good, efforts may be directed by leaving members alone as they perform their tasks to further strengthen trust through laissez-faire leadership since people are the lifeblood of the organization, thus, they must be valued. In addition, as leaders of educational institutions, they should employ approaches that are appropriate for different sets of purposes or circumstances to further improve the relationship with his team following the command and control leadership. With regards to situational leadership which also got a good rating, the school administrators should provide socio-emotional support and reinforcement, and develop followers slowly using a little more relationship behaviour as the follower increases 
in readiness. Finally, a sustainable leadership program based from the results and findings is recommended to be developed. The program can serve as a guide to the LUCs administrators and reference to other researchers in the near future.

\section{References}

Abida, K., Farah, N. \& Azeem, M. (2010). Gender Differences in Leadership Style at the University Level. International Journal of the Book. Common Ground Publishing LLC.

Anisur, M. \& Sultana, N. (2012). Innovative Leadership (People). The Jahangirnagar Journal of Business Studies, Vol. 2, No. 1.

Blanken Rhea, (2013), Eight (8) Common Leadership Styles. Available from: https://www.academia.edu/7060161/8_Common_Leadership_Styles

Cătălina Radu, Alecxandrina Deaconu and Corina Frăsineanu (February 1st 2017). Leadership and Gender Differences-Are Men and Women Leading in the Same Way?, Contemporary Leadership Challenges, Aida Alvinius, IntechOpen, DOI: $10.5772 / 65774$.

Ciolac, M. (2013). Male and Female Leadership - Similarities and Differences. Network Intelligence Studies. Vol. 1, Issue 2.

Cris, Joseph, (2015), Laissez Faire Leaders, Available from: http://www.josephchris.com/11-laissez-faire-leadership-style-examples

Eagly, Alice H. (2013), Gender and Work: Challenging conventional wisdom - A Research Symposium

Eagly, A.,H., Carli I., (2007), Through the labyrinth: The truth about how women become leaders, Cambridge Harvard Business School Press, MA, USA.

Eagly A.H., Schimidt M.C., (2007), Leadership Style Matters, Handbook on women in business and management. Available from: https://www.scholars.northwestern.edu/en/publications/the-leadership-styles-ofwomen-and-men

Ekmekci and Tosunoglu (2016). Laissez-Faire leaders and organizations: how does LaissezFaire leader erode the trust in organizations? Pressacademia 3(1). DOI: 10.17261/Pressacademia.2016116538 
Fraenkel, Jack R., Wallen, Norman E., (2007), How to Design and Evaluate Research in Education, McGraw-Hill Printing Press, NY, NY 10020

Henson, Rich (2013), Pacesetter Leadership: Do as I do, and do it now. Available at:http://blog.manageelitetraining.com/pacesetter-leadership-style

James Jarc, J. (2015). Laissez-Faire Leadership. Gonzaga Leadership Research Symposium

Keith, Kent M. (2017), Servant Leadership, Available at: http://www.toservefirst.com/definition-of-servant-leadership.html

Luthans, Fred (2011), Organizational Behavior: An Evidence-Based Approach, 12lfh Edition, Published by McGraw-Hill, Irwin, N.Y.,USA

Nikoloski, K. (2015). Charismatic Leadership and Power: Using the Power of Charisma for Better Leadership in the Enterprises. International Journal of Process Management New Technologies. Vol. 3, No. 2.

Podhorec, M., Hrinik, P. \& Lakos, G. (2017). Leadership in the Process of Command and Control, Place and Role of Commander-Manager. International conference KNOWLEDGE-BASED ORGANIZATION 23 (1). DOI: 10.1515/kbo-2017-0038

Robert, V., Vandenberghe, C. Laissez-Faire Leadership and Affective Commitment: the Roles of Leader-Member Exchange and Subordinate Relational Self-concept. J Bus Psychol (2020). https://doi.org/10.1007/s10869-020-09700-9

Sacavém, A., Martinez, L.F., Da Cunha, J.V., Abreu, A. \& Johnson, S.K. (2017). A Study On Delivery Styles, Mood, And Performance. Journal Of Leadership Studies, Volume 11, Number 3. DOI:10.1002/j1s.21519

Sirisookslip,S., Ariratana, W. \& Ngang, T. (2015). The Impact of Leadership Styles of School Administrators on Affecting Teacher Effectiveness. 5th World Conference on Learning, Teaching and Educational Leadership, WCLTA. Procedia - Social and Behavioral Sciences 186 ( 2015 ) 1031 - 1037 